\title{
Pakistani English Newspaper Paid Obituary Announcements: A Descriptive Analysis of the Transliterated Vocabulary
}

\author{
Sajid M. Chaudhry (Corresponding author) \\ Awang Had Salleh Graduate School of Arts and Sciences, Universiti Utara Malaysia, Malaysia \\ E-mail: sajid_mahmood@ahsgs.uum.edu.my \\ Anne A. Christopher \\ School of Education \& Modern Languages, College of Arts and Sciences, Universiti Utara Malaysia, Malaysia \\ E-mail: althea@uum.edu.my \\ Hariharan A/L N.Krishnasamy \\ School of Education \& Modern Languages, College of Arts and Sciences, Universiti Utara Malaysia, Malaysia \\ E-mail: hn1084@uum.edu.my
}

Doi:10.7575/aiac.alls.v.7n.4p.39

Received: 27/02/2016

URL: http://dx.doi.org/10.7575/aiac.alls.v.7n.4p.39

Accepted: 02/05/2016

\begin{abstract}
The study, qualitative and descriptive in nature, examines the use of transliteration in the paid Pakistani obituary announcements authored in the English language. Primarily, it identifies the frequently used transliterated vocabulary in these linguistic messages and reconnoiters the functional relationship that emerges in and between the textual moves of these announcements due to the linkage created by these transliterated words and phrases. Additionally, the study sheds light on the motives of the authors of these announcements behind opting for this lexical borrowing. Data, for the purpose, comes from the two prominent Pakistani English newspapers: The Dawn and The News International. The study concludes that the transliterated vocabulary used in the Pakistani English obituary announcements is a needbased, religiously and culturally enthused, lexical borrowing that not only helps the authors of these texts convey their intentional messages effectively but also enhances the exactness and spontaneity of the contents of these announcements.
\end{abstract}

Keywords: Obituary Announcement, Transliteration, Lexical borrowing, Source language, Target language, Cognitive synonyms

\section{Introduction}

Newspaper obituary, adhering to the delineation provided by the Oxford English Dictionary (1992), is "a record or announcement of a death or deaths, especially in a newspaper, usually comprising a brief biographical sketch of the deceased". Nwoye (1992) categorized it as a media genre having a specific communicative function. The first announcement of such kind was published in 1731 in a London based periodical known as The Gentleman's Magazine (Fowler, 2007, Bates, Monroe and Zhuang, 2009). With the passage of time, this journalistic text gained recognition as a distinctive genre in the field of print media and nowadays features regularly in the newspapers around the globe irrespective of their language of publication.

English dailies of Pakistani press, like their global counterparts, publish obituary announcements in their everyday printouts. These announcements are of two types: unpaid and paid. The unpaid obituaries are published as news items and editorials. Newspapers' designated staffers author these obituaries. These unpaid obituary announcements mainly celebrate the lives of the acclaimed elite of the bourgeois class of the Pakistani society. Newspaper managements have the prerogative to decide about the personalities entitled to this kind of obituary. Generally, it is observed that the people of high ranking in the fields of politics, civil and military bureaucracy, education, social welfare, etc. are delineated and honoured through these unpaid obituary announcements. The second kind of these announcements is of paid obituaries. Survivors of the deceased pay to the newspapers to get the obituaries of their loved-ones' published. Contents of these announcements are authored and provided by the survivors of the departed. Newspapers treat these paid obituary announcements as classified ads and print them as provided and/or as advised by the descendants of the deceased. This second form, paid obituary announcements, of the Pakistani English newspapers constitutes the research domain of the current study and it gyrates around the functionality of the transliterated vocabulary that, though semantically and grammatically optional, is commonly employed in these announcements and seems to be widely acknowledged by the Pakistani discourse community of this genre. The current study encompasses the identification, linguistic background, linguistic functionality and raison d'être for selection of these transliterated lexical items.

The researchers noted that despite the wide-scale reader-writer acceptability and the extensive usage of the transliterated vocabulary in the Pakistani English newspaper obituaries and the social and cultural cadence these transliterated words 
have, there exits limited research aimed at examining the use of this vocabulary. In order to fill this research gap, the present study attempts to examine the transliterated vocabulary of these Pakistani English announcements from a linguistic perspective. To do so, the current study first identifies the frequently transliterated vocabulary items in the Pakistani obituary genre and then as a next step examines the functional relationship that emanates from the discourse generic moves of these announcements due to the connections caused by the transliterated words. During the process both the spheres, overall obituary texts and the transliterated vocabulary, stay as the main areas of focus of the researchers.

\section{Literature Review}

Transliteration is a phonetic transcription that changes the alphabetical letters of the borrowed words of the source language into the analogous, similar-sounding alphabetical characters of the language in use. Pervouchine and Lin (2009) describe transliteration as a manner of rewriting words taken from a source language to a target language having a different writing structure using the loan words' phonological comparable equivalent. Writers, according to Mphahlele (2004), consider transliteration as the swiftest procedure to generate equivalents between the languages in use, the source and the target, and exercise it as a lexicographical and terminological principle. Transliteration, as per the observation of Al-Azami, Kenner, Ruby, and Gregory (2010), is a practical strategy that is adopted by the writers in such contexts where the written form of the target language is either unfamiliar or does not otherwise exist. Contrary to the translation that only provides the exact meanings of the borrowed vocabulary items, transliteration also helps the readers to utter the borrowed words in the similar way as they are pronounced in the source language. As per Regmi, Naidoo, and Pilkington (2010), the process of transliteration is adopted by the writers to replace and/or complement the words or meanings of the language in use with the meanings of borrowed words, as sometimes it becomes difficult for them to find the exact equivalence of the borrowed word in the target language. So, it helps in setting the right context for the better comprehension of the communicative purpose of the author(s). Transliteration is quite commonly applied while dealing with the religious scriptures the world over and is considered, as per the observation of Panourgia and Panourgia (1995), a reader-friendly act of the writers while dealing with the subject of death. ElShiekh and Saleh (2011) also believe that contrary to the translation that denotes abstract concept of the loaned words, transliteration conveys concrete impression of the borrowed terms if they are part of a religious discourse.

\section{Research Objectives}

These are the objectives of the research.

1. To ascertain the transliterated vocabulary that is frequently employed by authors of the Pakistani English newspaper paid obituary announcements.

2. To cognize the linguistic background of the transliterated vocabulary used in the Pakistani English newspaper paid obituary announcements.

3. To comprehend why the transliterated vocabulary is used by authors of the Pakistani English newspaper paid obituary announcements.

\section{Data}

601 paid obituaries published in the two prominent English newspapers of Pakistan, The Dawn and The News International, constitute the data for the current study. These obituaries were published in these newspapers during a year's time period starting from November 2011 onwards. The logic behind selecting these newspapers is, what Malik and Iqbal (2010) mentioned, their high circulation and large scale popularity among the people of the nation. The Dawn, according to Jan, Riaz Raza, Siddiq, and Saleem (2013), is the most widely distributed English newspaper of Pakistan with a nation-wide sway. Similarly, The News International as per the observation of Raza and Akbar (2012) enjoys a wide-scale readership in Pakistan. Along with the largescale readership, these two newspapers are perceived to be the authentic reflection of a wider canvas showcasing socio-cultural texture and values of Pakistani society. These two newspapers are also considered as pioneers for leading the linguistic trends in the emerging variety of Pakistani English. All these mentioned factors guided the researchers to select the paid obituary announcements published in these newspapers as a data base of the current study.

\section{Methodology}

The research is qualitative in its nature and a descriptive analysis, divulging on orthographical and structural schema of the paid English obituary announcements, is carried out to reach authentic conclusions. The analytical procedure started with the assumption that these paid obituary announcements of the Pakistani English newspapers are organized through certain discourse generic moves and therefore can be chunked into smaller textual units for the purpose of a thorough descriptive analysis. The process began with the identification of the transliterated vocabulary in the discrete textual moves and in their extended textual units; then based on this identification; it proceeded to describe the function of the transliterated terminology in its individualized capacity and also in totality with reference to the communicational load of these texts. As the transliterated words were semantically and grammatically detached from their host contextual units, the researchers did not feel any complexity while tagging them as a borrowed vocabulary. The researchers used all of their cognitive competence during the entire process in order to uphold the principles of reliability and validity. Furthermore, on a parallel basis, two independent raters substantiated the adopted analytical process, identification and the description provided by the researchers. 


\section{Results}

The analysis of the data reveals an abundance of the transliterated terminology in the Pakistani English newspaper paid obituary announcements. Evidently, it appears that transliteration in the Pakistani English obituary announcements is meant to enhance the accuracy and naturalness of their contents. It is observed that some textual moves of these announcements actually start with the transliterated words. Also, these transliterated words work as links to connect sentences into paragraph(s). In many cases these announcements contain heading consisting of the transliterated vocabulary. The overall picture that emerges after the analysis of the data depicts that the transliterated words in the Pakistani English obituary announcements are in fact lexically borrowed communicative tools that signal the way Pakistani obituary authors organize, develop and pass on their communicative intents through these texts. Also, it appears from the analysis that the use of these transliterated terms is closely linked to the communicative norms that govern the production and perception of these announcements in the English language. Table 1.1 depicts the most commonly used transliterated vocabulary with its source language(s).

Table 1 Commonly used Transliterated Words in the Pakistani English Newspaper Paid Obituaries

\begin{tabular}{|c|c|c|}
\hline Transliterated Form & Original Form & Source Language \\
\hline Inna LillahiwainnailayhiRajitun & 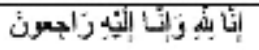 & Arabic \\
\hline Namaz e Janaza & تمازٍٍ جنزّه & Arabicilurdu \\
\hline Soyem & 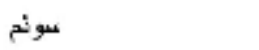 & Urdu \\
\hline Qul & ثt & Arrbic \\
\hline Quran Khawani & 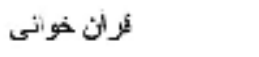 & Arabic/Persian \\
\hline Dua e Mughfrit & دعائه مغغرت & Arabic \\
\hline Ecsal e Sawab & اليصلا تُواب & Arabic \\
\hline Surah e Fateha & عنورة الذحكة & Arabic \\
\hline Ameen & أعبن & Arabic \\
\hline Masjid & ع عقد & Arabic \\
\hline Imam Bargah & 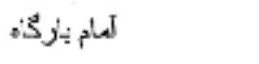 & Persian \\
\hline In Sha Allah & 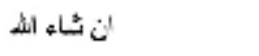 & Arabic \\
\hline Majlis & عجلس & Arabic'Persian \\
\hline Namaz & تصلز & Urdu \\
\hline Zohr & تخيج & Arabic \\
\hline Asr & عمبر & Arabic \\
\hline Maghrib & 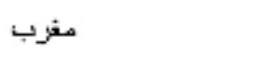 & Arabic \\
\hline
\end{tabular}

\section{Inna Lillahi wa inna ilayhi Raji'un}

Inna Lillahi wa inna ilayhi Raji'un is a Quranic verse in the Arabic language and in the English language it means that everyone belongs to the God Almighty and certainly everyone will be returning to Him. As far as the linguistic background of this verse is concerned, Muslims recite this verse at the times when they face misfortunes or unexpected setbacks in their day to day life affairs. Considering death as a major loss, Muslims on getting the news of a fellow Muslim's death recite this verse as their initial response to the news. The findings of this study divulge that the verse is quite frequently transliterated by the authors of the Pakistani English obituary announcements. The transliterated use of this verse is observed at levels of two different textual moves of these announcements: as a header and/or in between the text. As a header, it substitutes the conventional caption 'Obituary'. While, in the text, the verse's existence is noted in the third textual move of the Pakistani English newspaper paid obituary announcements that serves the communicative purpose of the death declaration. The given instances reflect the way the transliterated version of this Quranic verse appears in the texts of the Pakistani English obituaries.

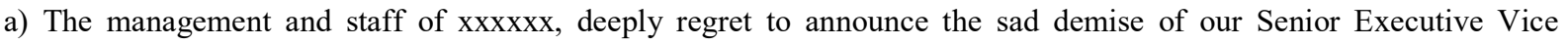
President \& Regional Head, Lahore Mr. xxxxxx. Inna Lillahi wa inna ilayhi Raji'un.

b) Our princess $\operatorname{xxxx} \mathrm{W} / \mathrm{O} \operatorname{xxxx}$ has passed away. Inna Lillahi wa inna ilayhi Raji'un. Please remember her in your prayers.

\section{Namaz e Janaza}

The term consists of two separate words belonging to the two different languages. The first word Namaz belongs to the Urdu language and in the English language it means "Prayer". The second word Janaza is from the Arabic language and in English it means "Funeral". As a compound noun in the Urdu language these words form a term that is used for 
the mandatory funeral prayer offered by the Muslims for their departed fellow Muslims. The analysis of the data reveals that the term is quite frequently used by the authors of Pakistani English obituaries to convey the time and date of such prayers. The following two examples portray the way this term is used in the texts of the Pakistani English newspaper obituaries. In addition, the term is also occasionally used as a heading of these announcements.

a) Today, $24^{\text {th }}$ Feburary 2012, Namaz e Janaza will take place after Zohar Prayer at about 2:15 PM at xxxxx, Karachi.

b) Her Namaz e Janaza will be offered in xxxxx, Islamabad, at 3:00 PM on 24 ${ }^{\text {th }}$ Feb. 2012 (Friday).

Soyem

The transliterated word of Soyem originally belongs to the Urdu language and means "Third" in the English language. In a post-death scenario, culturally and religiously, the word is attached to a ritual gathering in Pakistan that is called on the third day of the death of an individual by the left-behinds. The findings reflect the use of this transliterated word in two contexts: as a heading and as a reference to the third day post-death ritual. The given extracts demonstrate the way this word is used as a reference to the above mentioned third day post-burial ritual.

a) Soyem will be held between Asr and Maghrib on Friday, 3 February at house xxxxxx, Street xxxxx, DHA, Karachi.

b) Soyem of xxxxx who expired on 19 January, 2012 will be held on Saturday, 21 January, 9:00 AM at Yusufi Masjid, Tipu Sultan Road, Karachi.

\section{Qul}

The transliterated word Qul is linguistically borrowed from the Arabic language and means "Say" in the English language. Linguistically, the word originates from the four Quranic chapters (surahs) beginning with the word Qul. These four Quranic chapters are collectively referred to as Quls. During the post-burial gatherings, related to the death rituals, people in Pakistan mostly recite these Quls. The findings of the current study reveal that the word is used in two different references by the authors of the Pakistani English obituaries: as a heading of the death announcement and/or to mention the organized rituals where these Quls would be recited for the emancipation of the soul of the departed. Following are the examples reflecting the word's usage in reference to the post-burial rituals.

a) Quls for my beloved wife $\mathrm{xxxxx}$, sister of $\mathrm{xxxxx}$ who passed away at $\mathrm{xxxxx}$ on $18^{\text {th }} \mathrm{July}, 2012$ will be held on today (Saturday) $21^{\text {st }}$ July 2012 after Asr till Maghrib.

b) The Qul for xxxxx, W/O Late $\mathrm{xxxxx}$ who passed away on $24^{\text {th }}$ December 2011 will be held on $\mathrm{xxxxx}$ at $\mathrm{xxxxx}$ on Monday, $26^{\text {th }}$ December 2011 at 2:30 PM.

\section{Quran Khawani}

These transliterated words originally belong to two different languages. The word Quran is from the Arabic language and refers to the Islamic holy book Quran while the word Khawani belongs to the Persian language and means "Reading" in the English language. The term Quran Khawani exists as a compound noun in the Urdu language as well. Collectively, these words mean recitation of the holy Quran. In the perspectives of the post-death scenario, the term linguistically refers to the liturgy that is organized by the left-behinds of the dead to recite the holy Quran for the salvation of the departed soul of their loved-one in the world hereafter. Invitations are extended to the people for this post death congregation of Quran Khawani. In addition to this usage the term is also, optionally, used as a title of the Pakistani English newspaper death announcements. The following examples show the manner this term is used by the authors to inform the people about the practice related to the Quran Khawani.

a) Quran Khawani for the departed soul will be held today on Sunday, $26^{\text {th }}$ August at her residence xxxxx Upper Mall, Lahore after Asr prayers at 6:00 PM. By participating get the blessings of Allah.

b) With profound sadness, we announce the demise of our mother Mrs. xxxxx W/O late Mr. xxxxx. Quran Khawani will be held on Monday, $13^{\text {th }}$ August 2012 from 4:00 PM till 5:30 PM.

\section{Dua e Mughfrit}

The term Dua e Mughfrit means pleading for the God Almighty's forgiveness for the soul of the departed. Muslims on the death of a fellow Muslim offer Dua e Mughfrit to the God Almighty beseeching His kindness for the departed. The findings of the current study reveal that authors of the Pakistani English obituaries frequently use this transliterated term to inform and/or to request the readers of these texts to join the specifically arranged congregation of Dua e Mughfrit for the departed souls. It is observed, by the researchers, that infrequently only the word Dua (دعا) is also employed to communicate the analogous denotations. In addition to the aforementioned usage of the words, it is noted by the researchers that the term is also used by the authors as a header of these announcements and in this capacity it substitutes the traditional header obituary. The following excerpts are produced to reflect the way this term is used as a reference to the related religious gatherings where Dua e Mughfrit is offered.

a) Dua e Mughfrit for the departed soul will be held at his residence, xxxxx, Lahore after Asr at 6:00 PM. By participating get the blessings of Allah.

b) Dua will be held between 10:00 AM.to 11 AM on $1^{\text {st }}$ July 2012 at Sultan Masjid, Phase-V, DHA Karachi.

c) Mrs. xxxxx passed away on July $18^{\text {th }}, 2012$. Please recite Sura Fateha and offer Dua e Mughfrit for her departed soul.

d) We ask our friends and family to offer Dua to Allah to accept his good deeds and have mercy on his soul. 
Eesal e Sawab

The transliterated words Easal e Sawab linguistically originates from the Arabic language and convey the meanings "transferring or conveying of heavenly reward" to the soul of the departed. Left-behinds of the departed believe that the souls of their deceased relatives are the ultimate beneficiaries of all the prayers offered in the post-burial rituals. Basically, all the post-burial ritual gatherings are held with the purpose of Easal e Sawab to the departed soul and verses from the holy Quran are recited in such gatherings. Followings are the examples this transliterated term is employed in the Pakistani English obituaries.

a) The Soyem will be held on Sunday, the $13^{\text {th }}$ November 2011 from Zohar to Maghrib at his residence at xxxxx, North Karachi. Participation for Eesal e Sawab is requested.

b) Quran Khawani for Eesal e Sawab will be held at xxxxx, near Police Station on Wednesday 15 Feburary 2012 between Asr and Maghrib.

\section{Surah e Fateha}

These transliterated words are lexically borrowed from the holy Quran. The Arabic word Surah means "Part" in the English language while the Arabic word Fateha stands for "the Opening" in the English language. Surah e Fateha is actually an opening part of the holy Quran and is also the most recited Quranic part in the post death liturgies. Conventionally, the recitation of Surah e Fateha is followed by the recitation of Surah e Ikhlas, the last part of the holy Quran, three times. This conventional practice in Pakistan is collectively called offering Fateha for the soul of the departed. Here are the examples how these words are used in texts of the Pakistani English newspaper obituary announcements:

a) We regret to inform our friends and relatives that Mr. xxxxx S/O xxxxx, Ex-Director of xxxxx passed away on November 6, 2011 in Wisconsin USA. Recitation of Surah Al-Fateha is requested for his Eisal-e-Sawab.

b) Our beloved xxxxx passed away peacefully on January 09, 2012 in Chittagong, Bangladesh. Please recite Surah AlFateha for the departed soul.

c) With profound grief and sorrow, we announce the demise of our beloved xxxxx. Please recite Surah e Fateha and three times Surah e Ikhlas for his Eesal e Sawab.

\section{Ameen}

The transliterated word Ameen is linguistically loaned from the Arabic language and is used to conclude a Dua. The utterance of the word conveys the sense of strong agreement with the contents of the prayer and reflects ultimate faith and trust of Muslims in the blessings of the God Almighty. When the word Ameen is uttered at the end of a Dua, it is believed, by the Muslims, that the God Almighty will surely accept their requests of mercy for the departed soul. In the Pakistani English newspaper obituary announcements the word appears as reflected in the following reproduced sentences:

a) We announce with profound sorrow the passing away of our beloved Mr. xxxxx on Saturday, $4^{\text {th }}$ August 2012 . May his soul rest in eternal peace. Ameen!

b) May Allah grant his soul eternal peace and give strength and courage to the bereaved family to bear this irreplaceable loss. Ameen!

\section{Masjid / Imam Bargah}

Both the transliterated words, Masjid and Imam Bargah, are linguistically identical regarding the meanings they convey but the source languages of both the words are different. These words mean "Mosque" in the English language, a place where Muslims pray to Allah Almighty five times a day. The word Masjid is from the Arabic language while the word Imam Bargah belongs to the Persian language. In addition to the five regular daily prayers, Masjids and Imam Bargahs in Pakistan are also used by the Muslims to offer Namaz e Janaza for the departed souls. The findings of the current study reveal that these transliterated words are used to convey information about the place where the funeral prayers will be held. Also, these transliterated words are used if any post-burial ritual assembly is arranged by the survivors on such a place for the purpose of Quran Khawani for the departed soul. Following are the examples demonstrating the way these words are used in the Pakistani English obituary texts.

a) Soyem for her Eesal e Sawab will be held on $8^{\text {th }}$ December, 2011 between Asr and Maghrib prayers at Hilal Park Masjid, DHA, Karachi.

b) Quran Khawani and Dua for the departed soul will be held on Tuesday $3^{\text {rd }}$ Muharram (29 $9^{\text {th }}$ November) at Bara Imam Bargah, Model Town, Lahore.

c) Her Soyem will be held at Defense Imam Bargah Karachi between 3:00 PM and 5:00 PM on November 22, 2011 (Tuesday).

d) Namaz e Janaza for her will be held today (Tuesday) $29^{\text {th }}$ November 2011 after Namaz e Zohar at Muhammadi Masjid, Gulberg, Lahore.

\section{In Sha Allah}

The transliterated phrase In Sha Allah comes from the Arabic language. In the English language it means "if Allah Almighty wills so". Following religious guidance, Muslims are advised to say this phrase whenever they plan, propose 
or commit to do something in the days to come. The reason behind the utterance of this phrase is very simple. According to the Islamic religious belief, human beings cannot control their future destiny. Since, only the God Almighty knows what will happen, they ought not to make definite declarations about the future. To put it simply, future events always happen with the endorsement of the Almighty powers of the God. Examples displaying the use of this phrase in the Pakistani English obituaries are as follows:

a) She will be laid to rest in the Defense Graveyard in Lahore In Sha Allah on Friday, January 27, 2012.

b) The Namaz e Janaza of the departed soul will In Sha Allah be held at 1000 hrs. on $5^{\text {th }}$ March, Army Graveyard, Racecourse Road, Rawalpindi.

\section{Majlis}

The transliterated word Majlis is lexically borrowed from the Arabic language. It means assembly or gathering of many people together for a specific purpose. The findings of the current study reveal that the word Majlis is occasionally used by the authors of the Pakistani English language obituaries in reference with a post death ceremony that involves activities related to the Eesal e Sawab for the bygone soul: Quaran Khawani and/or recitation of Quls. In such a gathering, sometimes, religious leaders are called as guest speakers to elaborate the reality of death and dying in the light of religious preaching. The followings are the examples how this word is used in the Pakistani English death announcements:

a) Majlis for Eesal e Sawab will be held at Islamic Research Center, Ayesha Manzil on Friday, 20 Jan, 2012.

b) We are holding a Majlis of Quaran Khawani for him on Tuesday the 17 ${ }^{\text {th }}$ of May between 5:00 PM and 7:00 PM at xxxxx, Karachi. Please attend for Eesal e Sawab.

\section{Namaz e Zohr / Asr / Maghrib}

All these transliterated words, in their original form, linguistically belong to the Arabic language and are actually names of the three, out of five, mandatory prayers Muslims offer every day. These prayers are offered at three different timings of a day. Namaz e Zohar is offered around the afternoon. Namaz e Asr and Namaz e Maghrib are offered around the mid-evening and at sunset respectively. Analysis of the data reveals that survivors of the deceased generally use these prayer timings to arrange various pre and/or post-burial rituals like Namaz e Janaza, Soyem and Quaran Khawani . The followings are examples in this regard.

a) Soyem prayers for our beloved xxxxx will be held between Namaz e Zohar and Namaz e Maghrib on Friday, December $16^{\text {th }}, 2011$ at $x x x x x$, Phase VI, DHA, Karachi.

b) Namaz e Janaza will be held after Zohar prayers (1: 15 PM) on Saturday, $19^{\text {th }}$ November 2011 at Masjid e Abu Bakar.

c) Soyem of $\operatorname{xxxxx} \mathrm{S} / \mathrm{O}$ will be held between Namaz e Asr and Namaz e Maghrib on Friday, August 31, 2012 at xxxxxx.

\section{Discussion and Conclusion}

Pakistani English newspaper obituary appears to be a well-connected discourse that has the characteristics of a communicative occurrence that meets what De Beaugrande and Dressler (1981) mentioned as the seven standards of textuality: cohesion, coherence, intentionality, acceptability, informativity, situationality and intertextuality. With contextualized socio-cultural knowledge of death related events and by following the principle of analogy and the principle of local interpretation, the authors of these linguistic messages use transliteration in such a way that enhances the efficiency, effectiveness and appropriateness of the Pakistani English obituary announcements. The incorporation of the transliterated vocabulary helps the obituary genre of Pakistani English newspapers attain and accomplish the abovementioned seven standards of textuality.

It seems that in order to produce acceptable, natural and communicatively operative death announcements, obituary writers of Pakistan use transliterated vocabulary in a convincing way that is anticipated, perceived and acknowledged by the related discourse community. The researchers perceive that persistent occurrence of these transliterated words and phrases now integrates with the social and lingua-cultural fabric of the Pakistani society and hence can be considered as conventionalized or what ElShiekh and Saleh $(2011$, p.142) have mentioned as "cognitive synonyms". Consequently, the usage of the transliterated words or phrases like Inna Lillahi wa inna wa ilayhi Raji'un, Dua e Mughfrit, Namaz e Janaza, Soyem, Qul, Quran Khawani, etc. as headers, being substitutes of the word "obituary" of the Pakistani English death announcements, do not surprise the readers. In contrast, the information encoded in these transliterated vocabulary items, as headers and/or in between the lines, guides the readers' interpretation of these texts in line with the authors' religiously and culturally aligned communicative intentions. As a result, this creates a successful communicative situation in which these texts become effortlessly interpretable and achieve the intended communicative goals for which they are authored and published.

It can be determined, without any doubt, that transliterated vocabulary in the Pakistani paid English obituary announcements not only connects the discourse but also contributes to the cohesion of the overall texts of these announcements. These linguistic borrowings, from Arabic, Persian and Urdu languages, connect the textual moves of these announcements in a likely way to guide, influence and enhance the readers' construal capabilities throughout the texts. In addition to the imperative role that transliterated vocabulary plays in the production and perception of these texts, due to its consistency with the norms of Pakistani death culture, it also prevents the loss of meanings that might 
occur if authors of these announcements opt for the exact equivalents via translation in the target language. For example, the concrete concept provided by the use of transliterated words Namaz e Maghrib can never be conveyed through employing the corresponding translated words "Sunset Prayer". Semantically, the words "Sunset Prayer" are the accurate equivalents of the words Namaz e Maghrib in the English language but, in reality, convey an abstract concept of what the author of the Pakistani English obituary intends to convey. Similarly, the clarity of the communicative intent provided by the words Surah e Fateha can never be achieved with the incongruity of the meanings arising from these words' translated version "Opening Chapter".

The transliterated lexicography actually reflects that religious and cultural conventions dominate the death and post death protocols in the Pakistani society. This way, it gives us a glimpse into local society's religious disposition and how the people like to associate with religiosity. As, Pakistan is a predominantly Muslim society, it has a glare of Islamic culture not only in its day to day affairs but this reflection of the Islamic way of managing societal events is evident even in the death related discourses and rituals. The study of transliterated vocabulary in obituaries under discussion authenticates that, analyzing by any standards, this transliterated vocabulary welds the contents of these texts to the Islamic background of the society. In this context it would be quite pertinent to say here that religious beliefs of the Pakistani people mostly dictate the text and choice of the lexical borrowing is mostly determined by the aura of religious dogmas.

In short, the researchers perceive that transliterated vocabulary in the Pakistani English obituary announcements is a need-based, religiously and culturally inspired lending that helps the authors of these announcements communicate their intended messages effectually. Additionally, this transliterated vocabulary, by providing and strengthening contextual relationship between the source languages and the target language, enhances the accuracy and naturalness of these Pakistani English newspaper texts and generates conceptual equivalences that are widely accepted by the related local discourse community. Also, from the linguistic perspectives these transliterated terms are becoming a valuable source of vocabulary enrichment in the emerging localized variety of Pakistani English. Furthermore, it embarks upon us that English language has all the capacity to adopt and immerse new words and hence become a globally acceptable language, catering for the needs of all religious and cultural terrains and turfs. The researchers observe that the persistent existence and high frequency of these transliterated words will facilitate them to become part of international English.

\section{References}

Al-Azami, S., Kenner, C., Ruby, M., \& Gregory, E. (2010). Transliteration as a bridge to learning for bilingual children. International Journal of Bilingual Education and Bilingualism, 13(6), 683-700.

Bates, A., Monroe, I., Zhuang, M. (2009) The State of the American Obituary. Northwestern University. Retrieved from http://obitresearch.com/wpcontent/uploads/2009/11/StateOfThe AmericanObituary_Nov2009.pdf

De Beaugrande, R. and Dressler, W. (1981). Introduction to Text Linguistics. England: Longman.

ElShiekh, A. A. A., \& Saleh, M. M. A. (2011). Translation versus transliteration of religious terms in contemporary Islamic discourse in western communities. International Journal of English Linguistics, 1(2), 141.

Fowler, B. (2007). The obituary as collective memory. New York: Routledge.

Jan, M., Riaz Raza, M., Siddiq, M., \& Saleem, N. (2013). Print media on coverage of Political parties in Pakistan: Treatment of opinion pages of the 'Dawn' and 'News'. Gomal University Journal of Research, 29 (1), 118-128.

Malik, S. \& Iqbal, Z. (2010) Construction of Taliban image in Pakistan: Discourse analysis of editorials of Dawn and The News. China Media Research Journal, 7(2), 46-56.

Mphahlele, M. (2004). The transliteration principle: is this the best procedure in African language lexicography and terminology?. Lexikos, 14(1), 339-348.

Nwoye, O. G. (1992). Obituary announcements as communicative events in Nigerian English. World Englishes, (11), 15-27.

Oxford English Dictionary. (1992) $2^{\text {nd }}$ ed. On CD-ROM. Oxford: Oxford University Press.

Panourgia, E. N. K., \& Panourgiá, N. (1995). Fragments of death, fables of identity: An Athenian anthropography. Madison: University of Wisconsin Press.

Pervouchine, V., Li, H., \& Lin, B. (2009). Transliteration alignment. In Proceedings of the Joint Conference of the 47th Annual Meeting of the ACL and the 4th International Joint Conference on Natural Language Processing of the AFNLP.136-144.

Raza, M., \& Akbar, M. (2012). Image of President Asif Ali Zardari as portrayed by Daily Dawn and News: A Discourse Analysis of Editorials. J Mass Communicat Journalism, 2(4) 1-6. Regmi, K., Naidoo, J., \& Pilkington, P. (2010). Understanding the processes of translation and transliteration in qualitative research. International Journal of Qualitative Methods, 9(1), 16-26. 